\title{
DO WE PAY ENOUGH ATTENTION TO NEUROPATHIC PAIN IN KNEE OSTEOARTHRITIS PATIENTS?
}

\author{
Majda Golob ${ }^{1}$, Ivan Marković ${ }^{1}$, Neno Zovko ${ }^{1}$, Davorin Šakić \\ Ana Gudelj-Gračanin ${ }^{1}$ and Jadranka Morović-Vergles ${ }^{1}$
}

\begin{abstract}
${ }^{1}$ Division of Rheumatology and Clinical Immunology, Department of Internal Medicine, School of Medicine, University of Zagreb, Dubrava University Hospital, Zagreb, Croatia;

${ }^{2}$ Division of Physical Medicine and Rehabilitation with Rheumatology, Dubrava University Hospital, Zagreb, Croatia
\end{abstract}

\begin{abstract}
SUMMARY - The aim of the study was to determine the prevalence of neuropathic pain in knee osteoarthritis patients using painDETECT questionnaire, and to evaluate correlations between pain intensity, gender, age and types of treatment, and the presence of neuropathic pain. The study included 122 patients. All participants completed a questionnaire on sociodemographic data, duration of symptoms, types of treatment and preventable risk factors (body mass index and waist circumference). The presence of neuropathic pain was assessed by painDETECT, according to which subjects were classified into three groups (neuropathic pain likely, possible, or unlikely). Neuropathic pain was likely in 18 (14.8\%), possible in $30(24.6 \%)$ and unlikely in $74(60.7 \%)$ subjects. A significant positive correlation was found between visual analog scale for pain and painDETECT score. There was no statistically significant difference in gender, age, waist circumference and body mass index among three groups of participants according to painDETECT score. In conclusion, knee osteoarthritis patients with neuropathic pain component were experiencing higher levels of pain, implicating poorer pain control with common analgesics. Recognizing these patients as a distinct subgroup would allow clinicians to improve their treatment by using unconventional analgesics with central activity.
\end{abstract}

Key words: Osteoarthritis, knee; Pain management; Neuralgia; Analgesics; Surveys and questionnaires; Risk factors

\section{Introduction}

As one of the most common chronic musculoskeletal disorders, osteoarthritis (OA) is the leading cause of chronic disability in developed countries. Epidemiological studies estimate that about $15 \%$ of the world population is affected ${ }^{1}$. The incidence of $\mathrm{OA}$ is rapidly

Correspondence to: Prof. Jadranka Morovic-Vergles, MD, PhD, Division of Rheumatology and Clinical Immunology, Department of Internal Medicine, School of Medicine, University of Zagreb, Dubrava University Hospital, Avenija Gojka Šuška 6, HR-10000 Zagreb, Croatia

E-mail: jmorovic@kbd.hr

Received January 3, 2017, accepted December 27, 2017 increasing and the disease is becoming a considerable public health burden in terms of lost working days, early retirement and significantly increased healthcare costs $^{2}$.

Osteoarthritis is characterized by degenerative and inflammatory processes affecting mostly weight-bearing joints (hips, knees and ankles) and surrounding tissues, but any synovial joint can be affected ${ }^{1,3}$.

Pain is the most prominent clinical feature of OA and the main reason for physician office visits. The pathophysiology of pain in OA includes both nociceptive and neuropathic mechanisms. Abnormal excitability in pain pathways of peripheral and central ner- 
vous system corresponding to central sensitization has been demonstrated in $\mathrm{OA}^{2-4}$. The key pathological hallmark of $\mathrm{OA}$ is abnormal articular cartilage, which is avascular and aneural, and so cannot generate pain directly $^{3}$. Other articular and periarticular structures affected by the disease, such as synovial membrane, joint capsule, subchondral bone, periosteum, periarticular ligaments and muscles, are all richly innervated and represent the source of nociceptive pain ${ }^{2}$. Although the pain in OA has generally been classified as nociceptive (inflammatory), the component of neuropathic pain (NP) has been increasingly recognized in some patients ${ }^{3,5}$. Presumably, local damage to peripheral nerve fibers in articular and periarticular structures, in the course of disease, leads to activation of neuropathogenetic mechanisms ${ }^{3}$.

Clinically, early stage of OA is characterized by joint pain triggered by specific activities and relieved by rest ${ }^{6}$. Later, as the disease progresses, the pain often becomes constant ${ }^{7}$. A proportion of OA patients use descriptors characteristic of NP such as burning, numbness, 'pins and needles' to address their painful sensations. Also, mood changes, sleep disturbance and fatigue, which all are manifestations of chronic pain states, occur more frequently in OA patients ${ }^{3,4}$.

The goals of OA treatment are pain control, improvement of function and quality of life ${ }^{3}$. Currently available treatments provide only modest relief of pain at best. The effectiveness of some first-line agents, such as paracetamol, is hard to distinguish from placebo, and the effectiveness of nonsteroidal anti-inflammatory drugs (NSAIDs) and opioids is considered small to moderate 4 . A subgroup of OA patients, with poorly controlled pain by common analgesics (e.g., NSAIDs), has been shown to respond well to unconventional analgesics including tricyclic antidepressants, serotoninnorepinephrine reuptake inhibitors or gabapentinoids ${ }^{8}$.

The rationale for this study was based on observations that some of the knee OA patients with chronic pain experience both nociceptive pain and unrecognized NP. Presumably, these patients would tend to take higher doses of NSAIDs and report higher intensities of pain.

The aim of this cross-sectional study was to determine the prevalence of NP in knee OA patients using painDETECT questionnaire, and to evaluate the correlations between pain intensity, gender, age and types of treatment, and the presence of NP.

\section{Patients and Methods}

Study subjects were selected from outpatients diagnosed with knee OA attending the Division of Physical Medicine and Rehabilitation with Rheumatology, Dubrava University Hospital. These 122 patients were selected from 135 knee OA patients according to the following inclusion criteria: history of knee pain of at least 12 months and diagnosis of knee OA based on the American College of Rheumatology (ACR) classification criteria ${ }^{9}$. Exclusion criteria were a history of knee surgery, knee infection and rheumatoid arthritis.

All participants completed a self-administered questionnaire designed for this study, which included sociodemographic data (age and gender), duration of knee symptoms, types of treatment, and preventable risk factors (body mass index (BMI) and waist circumference). The presence of NP component was assessed by painDETECT questionnaire.

The study protocol was approved by Ethics Committee of Dubrava University Hospital and Institutional Review Board of Zagreb University School of Medicine. Informed consent was obtained from each participant.

\section{Pain scores}

Various screening tools have been developed to identify NP, including LANSS, DN4, NPQ, painDETECT, and ID Pain ${ }^{5}$. We chose painDETECT to determine the presence of NP in knee OA patients because it does not require clinical examination, and shows a slightly higher sensitivity and specificity $(85 \%$ and $80 \%$, respectively) in comparison to other validated questionnaires for assessment of $\mathrm{NP}^{5}$.

PainDETECT is a patient-based questionnaire consisting of nine items, i.e. seven weighted sensory descriptors and two items related to radiating and temporal characteristics of individual's pain pattern. The overall score ranges from 0 to 38 . A score $\geq 19$ indicates that NP is likely, a score 13-18 indicates that the presence of NP component is possible, and a score $\leq 12$ indicates that NP is unlikely. PainDETECT also includes visual analog scales (VAS) for pain referring to 3 different time points (pain at entry point, most severe pain in the past 4 weeks, and average pain in the past 4 weeks), but these items do not count towards the overall score. 


\section{Statistical analysis}

Data are presented in tables including absolute frequencies and their proportions, and arithmetic means with corresponding standard deviations. KolmogorovSmirnov test was applied to check for normality of data distribution, and according to the results obtained, the appropriate parametric tests were used. Differences in age, gender, BMI, waist circumference, VAS of pain at entry point, most severe pain in 4 weeks and average pain in 4 weeks among three groups of patients according to painDETECT score (neuropathic pain likely, possible, or unlikely) were analyzed by oneway ANOVA and Bonferroni post-hoc tests. The $\chi^{2-}$ test was used to analyze differences in categorical variables (treatment modalities), while correlations of VAS, gender, age, BMI, waist circumference and painDETECT score were evaluated by Pearson correlation coefficients. All $p$ values $<0.05$ were considered significant. The STATISTICA 10.0 (www.statsoft.com) software was used on analysis.

\section{Results}

The study included 122 participants ( 86 female and 36 male), mean age 64.6 years. All subjects had a history of knee OA of at least 12 months. The mean VAS of pain at entry point was 4.37 (SD 1.98, min 0.5, max 9.0); the mean VAS of the most severe pain during the last 4 weeks was 6.87 (SD 2.14, $\min 1.5, \max 10.0$ ); and the mean VAS of average pain during the last 4 weeks was 4.99 (SD 1.83, $\min 1.2, \max 10.0$ ).

According to painDETECT score, NP was likely (score $\geq 19)$ in $18(14.8 \%$ ), possible (score $\geq 13$ to $\leq 18$ ) in $30(24.6 \%)$, and unlikely (score $\leq 12)$ in $74(60.7 \%)$ subjects.

The most frequent pattern of pain in subjects with unlikely NP was "Pain attacks without pain between them", while subjects with possible and likely NP most frequently had the "Pain attacks with pain between them" pattern (Table 1).

A significantly higher proportion of participants with likely and possible NP $(36 / 48,75 \%)$ reported radiation of knee pain to other parts of leg than participants with unlikely NP $(17 / 74,22.97 \%)$ ( $<<0.001$, $\left.\chi^{2}=0.001\right)$. There was no significant difference in gender among subjects with likely, unlikely and possible $\mathrm{NP}\left(\chi^{2}=0.715\right)$.

All subjects with likely NP and $96.7 \%$ of subjects with possible NP were taking systemic NSAIDs compared to $73 \%$ of subjects with unlikely NP, which was statistically significant $\left(\chi^{2}=0.002, \mathrm{p}<0.01\right)$. Also, a significantly higher proportion of subjects with likely NP (83.3\%) were treated with topical NSAIDs than subjects with possible and unlikely NP $(53.3 \%$ and $50 \%$, respectively; $\left.\chi^{2}=0.037, \mathrm{p}<0.05\right)$. None of the participants was treated with opioid analgesics other than tramadol. There was no significant difference in other treatment modalities among the three groups (Table 2).

We found a significant positive correlation between VAS of pain at entry point and painDETECT score $(\mathrm{pc}=0.43, \mathrm{p}<0.001)$, VAS of most severe pain in 4 weeks and painDETECT score $(\mathrm{pc}=0.43, \mathrm{p}<0.001)$, and VAS of average pain in 4 weeks and painDETECT score $(\mathrm{pc}=0.43, \mathrm{p}<0.001)$. We also found a positive correlation between waist circumference and painDETECT score, which was not statistically sig-

Table 1. Types of pain in three groups of patients according to painDETECT score

\begin{tabular}{|c|c|c|c|c|c|c|}
\hline \multirow{2}{*}{\multicolumn{2}{|c|}{$\begin{array}{l}\text { PainDETECT } \\
\text { score }\end{array}$}} & \multicolumn{4}{|c|}{ Type of pain } & \multirow[b]{2}{*}{ Total } \\
\hline & & $\begin{array}{l}\text { Persistent pain with } \\
\text { slight fluctuations }\end{array}$ & $\begin{array}{l}\text { Persistent pain with } \\
\text { pain attacks }\end{array}$ & $\begin{array}{l}\text { Pain attacks without } \\
\text { pain between them }\end{array}$ & $\begin{array}{l}\text { Pain attacks with } \\
\text { pain between them }\end{array}$ & \\
\hline $0-12$ & $\begin{array}{l}\mathrm{n} \\
\%\end{array}$ & $\begin{array}{l}18 \\
24.3 \\
\end{array}$ & $\begin{array}{l}20 \\
27\end{array}$ & $\begin{array}{l}25 \\
33.8\end{array}$ & $\begin{array}{l}11 \\
14.9\end{array}$ & $\begin{array}{l}74 \\
100\end{array}$ \\
\hline $13-18$ & $\begin{array}{l}\mathrm{n} \\
\%\end{array}$ & $\begin{array}{l}1 \\
3.3 \\
\end{array}$ & $\begin{array}{l}7 \\
23.3\end{array}$ & $\begin{array}{l}10 \\
33.3\end{array}$ & $\begin{array}{l}12 \\
40\end{array}$ & $\begin{array}{l}30 \\
100\end{array}$ \\
\hline $19-38$ & $\begin{array}{l}\mathrm{n} \\
\% \\
\end{array}$ & $\begin{array}{l}1 \\
5.6 \\
\end{array}$ & $\begin{array}{l}1 \\
5.6\end{array}$ & $\begin{array}{l}3 \\
16.7\end{array}$ & $\begin{array}{l}13 \\
72.2\end{array}$ & $\begin{array}{l}18 \\
100 \\
\end{array}$ \\
\hline Total & $\begin{array}{l}\mathrm{n} \\
\%\end{array}$ & $\begin{array}{l}20 \\
16.4\end{array}$ & $\begin{array}{l}28 \\
23\end{array}$ & $\begin{array}{l}38 \\
31.1\end{array}$ & $\begin{array}{l}36 \\
29.5\end{array}$ & $\begin{array}{l}122 \\
100\end{array}$ \\
\hline
\end{tabular}


Table 2. Types of treatment in three groups of patients according to painDETECT score

\begin{tabular}{|c|c|c|c|c|c|c|c|}
\hline \multirow{3}{*}{ Type of treatment } & \multicolumn{7}{|c|}{ Patient groups according to painDETECT score } \\
\hline & \multicolumn{2}{|c|}{$0-12$} & \multicolumn{2}{|c|}{$13-18$} & \multicolumn{2}{|c|}{$19-38$} & \\
\hline & $\mathrm{n}$ & $\%$ & $\mathrm{n}$ & $\%$ & $\mathrm{n}$ & $\%$ & \\
\hline Laser therapy & 4 & 5.4 & 2 & 6.7 & 1 & 5.6 & 0.09 \\
\hline Magnetotherapy & 62 & 83.8 & 24 & 80 & 17 & 94.4 & 0.529 \\
\hline Electrotherapy & 19 & 25.7 & 12 & 40 & 9 & 50 & 0.398 \\
\hline Thermotherapy & 3 & 4.1 & 2 & 6.7 & 0 & 0 & 0.968 \\
\hline Ultrasound therapy & 4 & 5.4 & 1 & 3.3 & 1 & 5,6 & 0.898 \\
\hline Gymnastic exercises & 10 & 13.5 & 6 & 20 & 6 & 33.3 & 0.139 \\
\hline Systemic NSAIDs & 54 & 73 & 29 & 96.7 & 18 & 100 & 0.002 \\
\hline Topical NSAIDs & 37 & 50 & 16 & 53.3 & 15 & 83.3 & 0.037 \\
\hline $\begin{array}{l}\text { Paracetamol or paracetamol } \\
+ \text { tramadol }\end{array}$ & 14 & 18.9 & 5 & 17.2 & 6 & 33.3 & 0.349 \\
\hline Other opioid analgesics & 0 & 0 & 0 & 0 & 0 & 0 & - \\
\hline
\end{tabular}

NSAIDs = nonsteroidal anti-inflammatory drugs

nificant ( $\mathrm{pc}=0.01, \mathrm{p}=0.95)$, as well as negative correlation between age and $\mathrm{BMI}$, and painDETECT score, which was not statistically significant either $(\mathrm{pc}=-0.03$, $\mathrm{p}=0.74 ; \mathrm{pc}=-0.08$ and $\mathrm{p}=0.36$, respectively).

\section{Discussion}

Like nearly all other chronic pain states, OA is likely a 'mixed pain state', with individual variability in the relative balance of peripheral and central elements of pain ${ }^{10}$. OA-related pain is presumably the result of a complex interaction between local tissue damage, and inflammation, peripheral and central nervous system ${ }^{2}$. Inflammation in the joint triggers a cascade of events, resulting in peripheral sensitization, increased sensitivity of nociceptive primary afferent neurons, and hyperexcitability of nociceptive neurons in the central nervous system. Peripheral sensitization is thought to play an important role in the development and maintenance of central sensitization; intense, repeated or prolonged input from peripheral nociceptors modulates spinal cord pain-transmitting neurons and leads to decreased activation thresholds, increased synaptic excitability, and increased firing thresholds ${ }^{3}$. The presence of central sensitization is associated with a poor treatment outcome ${ }^{8}$.

This cross-sectional study showed that a significant proportion of OA patients manifested features of NP. Several other studies estimated the prevalence of NP in patients with OA using painDETECT score at 5\%$50 \% \%^{5,8}$. More recently, Ohtori et al. found that $5.4 \%$ of subjects with knee OA had likely NP and $15.2 \%$ had possible NP 5 . This study included 92 participants with the mean age of 70.4 years. In our study, the proportion of subjects with likely and possible NP was higher (14.8\% and $24.6 \%$, respectively), and the mean age of 122 participants was lower, 64.4 years. Age has been recognized as the most prominent risk factor for the initiation and progression of $\mathrm{OA}$, and the incidence of $\mathrm{OA}$ is higher in the elderly population, which can be explained by the cumulative effect of mechanical load resulting in 'wear and tear' of the joints ${ }^{11}$. Although we found a tendency of negative correlation between age and painDETECT score, implicating a higher likelihood of the presence of NP component in younger patients with knee OA, it was not statistically significant, and additional studies with larger samples are needed.

Besides the relatively small number of patients, another potential limitation of this study was that reliability of painDETECT for NP in knee OA had not been fully evaluated, and this needs to be assessed in further studies.

We also want to point out that despite treatment with analgesics and physical therapy, the level of pain in our subjects remained relatively high, as measured by VAS. Indeed, in a significant proportion of OA patients, pain is still inadequately controlled with com- 
mon analgesics, which leads to disability and impaired quality of life ${ }^{4}$.

Our results further indicated that knee OA patients with likely and possible NP experienced higher levels of pain and were more likely to take NSAIDs (both systemic and topical) than patients without NP component, implicating poorer pain control. A subgroup of OA patients with NP component, who may benefit from treatment with centrally acting analgesics such as opioids, antiepileptics, tricyclic antidepressants, and serotonin/norepinephrine receptor inibitors $^{8}$, mostly remain unrecognized. Implementation of a simple NP questionnaire in routine clinical practice would contribute to early recognition and appropriate treatment of these patients.

\section{Conclusion}

According to the painDETECT questionnaire, $14.8 \%$ of our participants likely had NP component, and another $24.6 \%$ possibly had it. These patients were experiencing higher levels of pain, implicating poorer pain control with common analgesics. Recognizing these patients as a distinct subgroup would allow clinicians to improve their treatment by using non-standard analgesics with central activity.

\section{References}

1. Egloff C, Hügle T, Valderrabano V. Biomechanics and pathomechanisms of osteoarthritis. Swiss Med Wkly. 2012;142: w13583. doi: 10.4414/smw.2012.13583
2. Salaffi F, Ciapetti A, Carotti M. The sources of pain in osteoarthritis: a pathophysiological review. Reumatismo. 2014; 66: 57-71. doi: 10.4081/reumatismo.2014.766

3. Mease PJ, Hanna S, Frakes EP, Altman RD. Pain mechanisms in osteoarthritis: understanding the role of central pain and current approaches to its treatment. J Rheumatol. 2011;38: 1546-51. doi: 10.3899/jrheum.100759. Epub 2011 Jun 1

4. Malfait AM, Schnitzer TJ. Towards a mechanism-based approach to pain management in osteoarthritis. Nat Rev Rheumatol. 2013;9:654-64. doi: 10.1038/nrrheum.2013.138. Epub 2013 Sep 17

5. Ohtori S, Orita S, Yamashita M, et al. Existence of a neuropathic pain component in patients with osteoarthritis of the knee. Yonsei Med J. 2012;53:801-5. doi: 10.3349/ymj.2012.53.4.801

6. Felson DT. Developments in the clinical understanding of osteoarthritis. Arthritis Res Ther. 2009;11:203. doi: 10.1186/ar2531. Epub 2009 Jan 30

7. Hawker GA, Stewart L, French MR, et al. Understanding the pain experience in hip and knee OA - an OARSI/OMERACT initiative. Osteoarthritis Cartilage. 2008;16:415-22. doi: 10.1016/j.joca.2007.12.017. Epub 2008 Mar 4

8. Thakur M, Dickenson AH, Baron R. Osteoarthritis pain: nociceptive or neuropathic? Nat Rev Rheumatol. 2014;10:374-80. doi: 10.1038/nrrheum.2014.47. Epub 2014 Apr 1

9. Altman RD. Classification of disease: osteoarthritis. Semin Arthritis Rheum. 1991;20:40-7.

10. Phillips K, Clauw DJ. Central pain mechanisms in chronic pain states - maybe it is all in their head. Best Pract Res Clin Rheumatol. 2011;25:141-54. doi: 10.1016/j.berh.2011.02.005

11. Hügle T, Geurts J, Nüesch C, Müller-Gerbl M, Valderrabano V. Aging and osteoarthritis: an inevitable encounter? J Aging Res. 2012;950192. doi: 10.1155/2012/950192. Epub 2012 Jun 7. 
Sažetak

\section{POKLANJAMO LI DOVOLJNO POZORNOSTI NEUROPATSKOJ BOLI U BOLESNIKA S OSTEOARTRITISOM KOLJENA?}

\section{Golob, I. Marković, N. Zovko, D. Šakic, A. Gudelj-Gračanin i J. Morović-Vergles}

Cilj ovoga rada bio je odrediti učestalost neuropatske boli u bolesnika oboljelih od osteoartritisa koljena primjenom upitnika painDETECT te istražiti povezanost prisustva neuropatske boli s intenzitetom boli, spolom i dobi bolesnika te modalitetom liječenja. U istraživanje je bilo uključeno ukupno 122 bolesnika. Svi ispitanici ispunili su upitnik koji je uključivao sociodemografske podatke, podatke o indeksu tjelesne mase i opsegu struka. Prikupljani su i podaci o trajanju simptoma i modalitetima liječenja. Prema podacima dobivenim pomoću upitnika painDETECT bolesnici su svrstani u tri skupine: one koji imaju prisutnu komponentu neuropatske boli, one koji je možda imaju i one kod kojih ona nije prisutna. Rezultati su pokazali da je komponenta neuropatske boli prisutna kod 18 ispitanika, moguća kod njih 30, dok 74 ispitanika nije imalo elemenata koji bi govorili u prilog postojanju neuropatske boli. Rezultat upitnika painDETECT značajno je korelirao $s$ vizualno analognom ljestvicom boli. Istraživanjem nismo dokazali statistički značajnu povezanost dobi, spola, opsega struka $\mathrm{i}$ indeksa tjelesne mase s prisustvom neuropatske boli. Bolesnici s osteoartritisom koljena koji imaju prisutnu komponentu neuropatske boli trpe bol koju ne ublažavaju standardni analgetici. Prepoznavanje te skupine bolesnika među oboljelima omogućilo bi njihovo uspješnije liječenje nestandardnim analgeticima centralnog djelovanja.

Ključne riječi: Osteoartritis, koljeno; Bol, liječenje; Neuralgija; Analgetici; Ankete i upitnici; Rizični čmbenici 